\title{
Development and characterization of dumpling dough with 'optimal' dietary fibre ratio using Ofada rice (Oryza Sativa L) and unripe plantain (Musa Paradisiaca AAB) fruit
}

\author{
Gibson Lucky Arueya* and Olaide Akande \\ Department of Food Technology, University of Ibadan, Ibadan, Nigeria
}

\begin{abstract}
Dumpling doughs are often made from tuber or cereal flours characterized by high calories and a non-optimal dietary fibre ratio. Increasingly, these doughs are being linked to overweight and obesity. Development, evaluation and use of doughs from Ofada rice and unripe plantain fruit flour blends may make some difference, hence this study.

Ofada Rice and unripe plantain flours were analysed for dietary fibre fractions [Insoluble (IDF), soluble (SDF)] with their ratio (IDF/SDF) related to selected blending proportions [(Ofada:Plantain, (100:0) - (0:100)]. Proximate composition and functional properties of these blends were determined following established procedures. Each of these blends were made into dough according to standard methods. Sensory evaluation followed afterwhich the best two blends in overall sensory score and dietary fibre ratio close to optimum were pelletized. These were fed Wistar Rats while monitoring the hypocholesterolemic and weight gain potential of the diets. All data were subjected to statistical analysis $(\mathrm{P} \leq 0.05)$.

The IDF:SDF ratios of Ofada Rice and Plantain flours were 2.2:1, 3.7:1 respectively with those for replacement blends [Ofada:Plantain, (100:0) - (0:100)] falling within the bracket. Proximate components [Carbohydrate (76.94-78.35\%), Crude fibre (0.27- 0.73\%), Protein (8.18-8.7\%), Fat (0.55-1.69\%), Moisture (10.4-11.2\%)] and functional properties (peak viscosity 19.36-602.97 RVU; swelling power (32.2-143\%), bulk density $\left.0.70-0.87 \mathrm{~g} / \mathrm{cm}^{3}\right)$ were within limits. Dumpling doughs so produced, and their sensory scores showed that the Ofada-plantain blends [(85:15) IDF/SDF, 2.4:1); (50:50) (IDF/SDF 2.8:1)] were the two most preferred in that order. Following this trend, Animal studies further indicated that these blends exert significant reduction in cholesterol (Low density lipoprotein (LDL) (48.7-53.9\%) and a desirably low weight gain potential (6.3-8.4\%) as against marked increases observed in control.
\end{abstract}

An acceptable dumpling dough with appropriate dietary fibre ratio (IDF/SDF, 2.4:1) has been developed. Its application as a functional food can make a difference in the onset and progression of overweight and obesity.

\section{Introduction}

Dumplings, a globular mass of dough (stewed, boiled, fried or baked) produced from available staples remains a regular component (with or without fillings) of food intakes across many regions of the world. They come in different variants driven by cultural preferences and tastes.

In Sub-saharan Africa, these doughs or food gel are variously processed traditionally from cereals or tubers. They come with indigenous names and include those based on cassava ('eba', 'fufu', 'akpu', 'lafun'), maize ('tuwo masara,' 'agidi,' 'banku', 'kenkey') and yam ('iyan', 'amala') [1-3]. These dumplings are consumed regularly first by hand-molding them into small balls and swallowed without chewing along with soup or stew delicacies [4] Nutritionally, these doughs are associated with high calories and a less than beneficially optimum insoluble/soluble dietary fibre fraction ratio (IDF/SDF) revolving around their predominant raw material flour input [11:1 (cassava); 6:1 (maize); 6:1 (yam)] [1,5,6]. These values are significantly different from the generally accepted IDF/SDF ratio $(2: 1)[7,8]$ crucial for good dietary and functional properties [9]. It is instructive therefore to note that high consumption of dumplings amongst other foods with similar properties have been linked to incidences of overweight and obesity [10,11]. Moderate adjustment involving dietary fibre have shown promise in promoting weight loss and reduced risk of chronic diseases in humans $[12,13]$. In the light of the foregoing, there is need to explore available dietary staples in the formulation and use of a flour base close to or with an optimum dietary fibre ratio (IDF/SDF) (2:1). Ofada rice (Oryza sativa L) and unripe plantain (Musa Paradisiaca AAB) fruit (sometimes called cooking bananas) - two staples in the sub-saharan region of Africa, holds promise in these respects.

Ofada rice had been classified as a peculiar form of Oryza sativa species [14]. It is an unpolished short grain upland rice high in fibre (3.5\%) with red kernels not found in any other rice. This rice is specially

${ }^{\star}$ Correspondence to: Gibson Lucky Arueya, Department of Food Technology, University of Ibadan, Ibadan, Nigeria, Tel: 234-805-9546-297; Fax: 234(02)8103043; E-mail: arueyagibson@yahoo.com

Key words: dumpling dough, Dietary fibre ratio, overweight, obesity, hypocholesterolemia

Received: May 15, 2018; Accepted: June 05, 2018; Published: June 14, 2018 
relished because of its characteristic flavour that develops during soaking following fermentative activities of some micro-organisms [15]. Plantain on the other hand is a perennial tropical crop found especially in Africa, the Caribbean, Latin America, Asia and the pacific [16]. The plantain fruit (unripe) is high in dietary fibre (6-15.5\%) with good level of hemicellulose $(6.08 \%)$ than most fruits and vegetables [17]. The mature fruits (ripe or unripe) are consumed boiled, steamed, baked, pounded, roasted or sliced and fried.

Dumplings made from traditional staple sources is a regular part of the food intakes for many in Sub-saharan Africa where overweight/ obesity is currently an emerging problem [18]. Developing an acceptable flour base with an appropriate fibre fraction ratio for a more healthful dumpling dough as a strategy to mitigate this challenge has become more imperative. This constitutes the objective of this work as well as characterization of its chemical, sensory, functional and nutritional properties.

\section{Materials and methods}

\section{Sourcing of raw materials}

Ofada rice and Green matured plantain used for this study were obtained from Bodija and Oje markets in Ibadan, Oyo state, Nigeria.

\section{Raw material pre-processing and preliminary evaluation}

Preparation of Ofada rice flour: Ofada rice flour was prepared by sun drying the Ofada rice $(10 \mathrm{~kg})$, followed by sorting to remove unwanted particles and then milled using a single disc mill (model 1A Sukhsa exports, India). The resulting milled flour was sieved through $250 \mu \mathrm{m}$ aperture screen.

Preparation of unripe plantain flour: Plantain flour was produced according to the method of Ogazi [19] with some modifications. Green matured plantain fruits (weighing $15 \mathrm{~kg}$ ) were washed, blanched at $100^{\circ} \mathrm{C}$ for 5 mins, cooled in a water bath and thereafter peeled. The fruit was next sliced ( $2 \mathrm{~mm}$ thick) and dried in an oven set at $65^{\circ} \mathrm{C}$ for $48 \mathrm{hr}$. Milling into flour using a single disc mill and subsequent sieving through $250 \mu \mathrm{m}$ aperture sieve followed. The flour was packed and sealed in zip lock polyethylene bags until analyzed.

Chemical evaluation of dietary fibre of rice and plantain flour: Ofada rice Flour (ORF) and Unripe plantain flour (UPF) were separately analyzed for Dietary fibre - soluble dietary fibre (SDF), Insoluble dietary fibre (IDF) and Total dietary fibre (TDF) content. This was done using enzymatic gravimetric method [20].

Twenty grams ( $20 \mathrm{~g}$ ) of sample was weighed into $500 \mathrm{ml}$ beaker with $50 \mathrm{ml}$ of distilled water added followed by heating at $100^{\circ} \mathrm{C}$ for 30 mins. Three millilitres ( $3.0 \mathrm{ml}$ ) of $\alpha$-amylase was next added along with $5.0 \mathrm{ml}$ of phosphate buffer. The entire sample mix was adjusted to $\mathrm{pH} 6.0$ and placed in a water bath at a temperature of $95-100^{\circ} \mathrm{C}$. This was closely followed by the addition of $2.0 \mathrm{ml}$ of protease and then allowed to cool to room temperature. Thereafter the $\mathrm{pH}$ of the sample was adjusted to $\mathrm{pH} 7.5$ and made to stand for $30 \mathrm{mins}$ at $60^{\circ} \mathrm{C}$. A further $\mathrm{pH}$ adjustment ( $\mathrm{pH}$ 4.5) was done with a subsequent addition of Aminoglucosidase (enzyme) and then incubation at $60^{\circ} \mathrm{C}$ for another 30 mins. Some two hundred and eighty millilitres $(280 \mathrm{ml})$ of ethanol $(95 \% \mathrm{v} / \mathrm{v})$ at $60^{\circ} \mathrm{C}$ was next added to the mix and left to stand again for 60 minutes at room temperature to effect complete precipitation. The entire mix was then subjected to centrifugation and the residue collected. Soluble and Insoluble fibres were calculated gravimetrically in a pre-weighed crucible and dried at $105^{\circ} \mathrm{C}$ for $5 \mathrm{hrs}$ to constant weight.
Mixing and preparation of flour blends: Blends containing varying proportions of Ofada rice flour together with Plantain flour were prepared by mixing requisite amounts (\%) (Table 1) depending on the dietary fibre content ranging from 2.2:1 to 3.8:1 (IDF:SDF) [((Ofada rice (IDF:SDF; 2.2:1)); Plantain (IDF:SDF; 3.8:1))].

\section{Proximate analysis of flour blends}

Proximate components (moisture, crude protein, ash, crude fat, crude fibre and carbohydrate) were determined according to the Association of Official and Analytical Chemists [21].

\section{Energy content determination}

The energy content (E) was calculated using Atwater factor [22] as:

$\mathrm{E}=(4 \times \mathrm{P})+(9 \times \mathrm{F})+(4 \times \mathrm{C})(1)$

Where:

$$
\begin{aligned}
& \mathrm{P}=\text { protein content }(\%) \\
& \mathrm{F}=\text { fat content }(\%) \\
& \mathrm{C}=\text { carbohydrate content }(\%)
\end{aligned}
$$

\section{Determination of $\mathrm{pH}$}

$\mathrm{pH}$ was determined using hand held $\mathrm{pH}$ meter (model BA 50). Five grams of the flour sample was weighed into a beaker containing $25 \mathrm{ml}$ of distilled water. It stood for 30 minutes with constant stirring. The $\mathrm{pH}$ was then determined using the $\mathrm{pH}$ meter.

\section{Determination of functional properties}

Bulk density: Bulk density was determined using the method of Akpapunam and Markakis [23]. Ten grams (10 g) of sample was weighed into $50 \mathrm{ml}$ graduated measuring cylinder. The sample was packed by gently tapping the cylinder on the bench top several times until there was no more decrease in volume. The volume of the compacted sample was recorded, and the bulk density was calculated as follows.

Bulk density $(\mathrm{g} / \mathrm{ml})=$ Weight of sample $(\mathrm{g}) /$ Volume of sample after tapping $(\mathrm{ml}) \rightarrow(2)$

Swelling power and solubility index: Swelling power and solubility index were determined using the method described by Takashi and Sieb [24]. It involved weighing $1 \mathrm{~g}$ of the sample into $50 \mathrm{ml}$ centrifuge tube. Some $50 \mathrm{ml}$ of distilled water was added and mixed gently. The slurry was heated in a water bath at $80^{\circ} \mathrm{C}$ for $15 \mathrm{~min}$. During heating, the slurry was stirred gently to prevent clumping of the flour. On completion of $15 \mathrm{~min}$, the tube containing the paste was centrifuged at $3000 \mathrm{rpm}$ for $10 \mathrm{~min}$. The supernatant was decanted immediately after centrifuging. The weight of the sediment was taken and recorded. The moisture content of the sediment gels was therefore determined so as to

Table 1. Preparation of flour blends (Note that: Sample KDV is $100 \%$ Ofada flour, LYF is $85 \%$ Plantain flour and $15 \%$ Ofada flour, MPU is $65 \%$ Plantain flour and $35 \%$ Ofada flour, EBG is $50 \%$ Plantain flour and 50\% Ofada flour, CKQ is 30\% Plantain flour and $70 \%$ Ofada flour, NXS is $15 \%$ Plantain flour and $85 \%$ Ofada flour while JZH is $100 \%$ Plantain flour)

\begin{tabular}{|c|c|c|}
\hline Sample identification & Ofada rice flour (\%) & Plantain flour (\%) \\
\hline KDV & 100 & 0 \\
\hline LYF & 15 & 85 \\
\hline MPU & 35 & 65 \\
\hline EBG & 50 & 50 \\
\hline CKQ & 70 & 30 \\
\hline NXS & 85 & 15 \\
\hline JZH & 0 & 100 \\
\hline
\end{tabular}


get the dry matter content of the gel. The swelling power and percentage solubility index was calculated using the equation below.

Swelling power $=$ Weight of wet mass sediment/Weight of dry matter in the gel (3)

Solubility index $(\%)=$ Weight of dry solid after drying $\times 100(4)$

Water absorption capacity: Water absorption capacity was determined by using the modified method of Elkalifa et al. [25]. Fifteen grams (15 g) of the samples was weighed accurately with some water added. It was next centrifuged at $3250 \mathrm{rpm}$ for $25 \mathrm{~min}$ and thereafter the supernatant decanted. The residue left was air dried and weighed.

Pasting properties: This was determined using the Rapid Visco Analyzer (model no. RVA 4 Newport Scientific, Warrie-wood Australia) [26]. Some sample (3.5 g) were weighed into a weighing vessel with aliquot amount of distilled water $(2.5 \mathrm{ml})$ and the mix dispensed into test canister. The paddle and canister assembly were inserted firmly in the RVA and the measurement cycle initiated. Each suspension was kept at $50^{\circ} \mathrm{C}$ for $1 \mathrm{~min}$ and thereafter temperature raised to $95^{\circ} \mathrm{C}$ (at $12.2^{\circ} \mathrm{C} \mathrm{min}^{-1}$ ) The sample mix was held for $2.5 \mathrm{~min}$ at $95^{\circ} \mathrm{C}$ and then cooled to $50^{\circ} \mathrm{C}$ (at $11.8^{\circ} \mathrm{C} \mathrm{min}{ }^{-1}$ ). This was left to stand for 2 min (at $50^{\circ} \mathrm{C}$ ) and subsequently terminated automatically. Data on pasting properties were then obtained.

\section{Preparation of the dough}

The samples obtained from the different fractions of Ofada-plantain mixes were made into dough using about $200 \mathrm{~g}$ of flour stirred in 60 $\mathrm{ml}$ of boiling water and allowed to cook on fire while kneading with a wooden baton for about 10 minutes. A wheat dough was similarly prepared for comparative evaluation.

\section{Sensory evaluation}

Sensory evaluation was carried out on the reconstituted Ofadaplantain paste and its equivalent (wheat dough meal) using a preference test where 1 represented dislike extremely and 9 represented like extremely. Wheat dough meal was used as a reference. Thirty panellists who were familiar with the sensory properties of dough meal were asked to score the samples in terms of texture, colour, taste, mouldability, odour, mouth feel and overall acceptability using the nine-point hedonic scale. All samples (seven in all) were evaluated.

\section{Nutritional evaluation}

Animals: Twenty Wistar Albino Male rats (3 weeks old) were obtained from Anatomy department, University of Ibadan, Ibadan, Nigeria and were given feed and Water ad libitum for 2 weeks as part of acclimatization. After this and at the start of the induction, the rats had an average weight of $(100 \pm 14) \mathrm{g}$. These were divided into 4 treatment groups of 5 rats per treatment and housed 5 per cage in plastic cages with wire meshed covers. They were kept at a room temperature of $\left(25 \pm 2^{\circ} \mathrm{C}\right)$ with lighting from 7 am to $7 \mathrm{pm}$.

The study was performed following ethical clearance by the Animal Care and Use Research Ethics Committee (ACUREC), University of Ibadan, Ibadan, Nigeria.

Animal diets: The experimental diets are as depicted (Table 2). In preparing the high cholesterol diet (HCD), the basal chow pellet was first milled and blended with cholesterol and Cholic acid $(0.1 \%)$. Experimental diets were formulated by substituting 50\% of corn starch component of the basal diet with composite Ofada rice and plantain flours. All feed mixtures were pelletized and oven dried $\left(60 \pm 2^{\circ} \mathrm{C}\right)$ for 24 Hours.
Table 2. Composition of different experimental diets (CON is Basal diet; HCD is High cholesterol diet; Ofada-Plantain (50:50) is $\mathrm{HC}+$ Ofada rice flour $50 \%$ and Plantain flour $50 \%$; Ofada-Plantain (85:15) is $\mathrm{HC}+$ Ofada rice flour $85 \%$ and Plantain flour $15 \%$ )

\begin{tabular}{|c|c|c|c|c|}
\hline $\begin{array}{c}\text { Ingredients } \\
\mathbf{( g / k g )}\end{array}$ & CON & HCD & $\begin{array}{c}\text { Ofada-Plantain } \\
\mathbf{( 5 0 : 5 0 )}\end{array}$ & $\begin{array}{c}\text { Ofada-Plantain } \\
\mathbf{( 8 5 : 1 5 )}\end{array}$ \\
\hline Corn Starch & 648 & 637 & 137 & 137 \\
\hline Pre-mix & 20 & 20 & 20 & 20 \\
\hline Vegetable Oil & 100 & 100 & 100 & 100 \\
\hline Bone meal & 20 & 20 & 20 & 20 \\
\hline Oyster Shell & 10 & 10 & 10 & 10 \\
\hline Glucose & 50 & 50 & 50 & 50 \\
\hline Cellulose & 50 & 50 & 50 & 50 \\
\hline Sucrose & 100 & 100 & 100 & 100 \\
\hline Salt & 2 & 2 & 2 & 2 \\
\hline Cholesterol & - & 10 & 10 & 10 \\
\hline Cholic acid & - & 1 & 1 & 1 \\
\hline Ofada rice flour & - & - & 250 & 425 \\
\hline Plantain Flour & - & - & 250 & 75 \\
\hline
\end{tabular}

Experimental design: Following two weeks of acclimatization the rats were randomly separated into four groups of five each. The first group was fed with basal diet (control diet) while second, third and fourth groups had high cholesterol(HCD), high cholesterol+ Ofada plantain (50:50), and high cholesterol + Ofada - plantain (85:15) diets respectively. These feeding regimens (including water ad libitum) were maintained for two weeks (induction period) [Each rat in a group of five were marked with different coloured markers (namely Red, Blue, Green, black and one unmarked) for easy identification]. Blood samples of the rats were collected at this juncture after 12 hours of fasting, following which the feeding regimen continued for another two weeks. A second blood sampling was next conducted at the end of this treatment period. Throughout the feeding duration, food and water were replenished at 10 am every day.

\section{Biochemical parameters}

Blood samples $(2.5 \mathrm{ml})$ collected into tubes using ocular puncture under chloroform were used for these evaluations. Samples were centrifuged at $3000 \mathrm{rpm}$ for 10 minutes at $4^{\circ} \mathrm{C}$. The resulting sera were separated for lipid profile analysis namely High-Density Lipoprotein (HDL), Total Cholesterol (TC) and Triglyceride (TG) by using automatic analyser (DT 60 II autoanalyzer (Falladen, Switzerland)). The Low-Density Lipoprotein (LDL) was calculated as follows.

$\mathrm{LDL}=\mathrm{TC}-(\mathrm{HDL}+\mathrm{TG} / 5) \rightarrow(5)$

Where,

LDL is low density lipoprotein

TC is total cholesterol

HDL is high density lipoprotein and

TG is triglyceride

\section{Statistical analysis}

All data were subjected to analysis of variance (ANOVA) using SPSS version 16.0 for windows, SPSS Inc. Means were separated using Duncan's Multiple Range Test.

\section{Results and discussion}

\section{Evaluation of dietary fibre profiles of samples}

Plantain and Ofada rice flours: The plantain flour had a dietary fibre content (g/100 g) dry matter (DM) $(13.12 \pm 0.03)$ (Table 3$)$ and this 
Table 3. Dietary fibre fractions of plantain and Ofada flours and the IDF/SDF ratios of their blends

\begin{tabular}{|c|c|c|c|c|}
\hline \multicolumn{5}{|c|}{ (a) Dietary fibre composition (g/100 g DM) and IDF/SDF ratio } \\
\hline SAMPLE & IDF & SDF & TDF & IDF:SDF \\
\hline Plantain & $10.32 \pm 0.02$ & $2.81 \pm 0.02$ & $13.12 \pm 0.03$ & $3.68: 1$ \\
\hline Ofada & $3.20 \pm 0.01$ & $1.45 \pm 0.02$ & $4.65 \pm 0.01$ & $2.22: 1$ \\
\hline \multicolumn{5}{|c|}{$\begin{array}{c}\text { Values are Mean } \pm \text { standard deviation, IDF - Insoluble dietary fibre; SDF - Soluble } \\
\text { dietary fibre; TDF - Total dietary fibre. }\end{array}$} \\
\hline \multicolumn{5}{|c|}{ (b) IDF/ SDF ratios of different proportions of Plantain and Ofada flour blends } \\
\hline \multicolumn{2}{|c|}{ Plantain } & \multicolumn{2}{|c|}{ Ofada (g) } & IDF:SDF \\
\hline \multicolumn{2}{|c|}{100} & \multicolumn{2}{|c|}{0} & $3.7: 1$ \\
\hline \multicolumn{2}{|c|}{95} & \multicolumn{2}{|c|}{5} & $3.7: 1$ \\
\hline \multicolumn{2}{|c|}{90} & \multicolumn{2}{|c|}{10} & $3.5: 1$ \\
\hline \multicolumn{2}{|c|}{85} & \multicolumn{2}{|c|}{15} & $3.4: 1$ \\
\hline \multicolumn{2}{|c|}{80} & \multicolumn{2}{|c|}{20} & $3.3: 1$ \\
\hline \multicolumn{2}{|c|}{75} & \multicolumn{2}{|c|}{25} & $3.3: 1$ \\
\hline \multicolumn{2}{|c|}{70} & \multicolumn{2}{|c|}{30} & $3.2: 1$ \\
\hline \multicolumn{2}{|c|}{65} & \multicolumn{2}{|c|}{35} & $3.1: 1$ \\
\hline \multicolumn{2}{|c|}{60} & \multicolumn{2}{|c|}{40} & $3.0: 1$ \\
\hline \multicolumn{2}{|c|}{55} & \multicolumn{2}{|c|}{45} & $2.9: 1$ \\
\hline \multicolumn{2}{|c|}{50} & \multicolumn{2}{|c|}{50} & $2.8: 1$ \\
\hline \multicolumn{2}{|c|}{45} & \multicolumn{2}{|c|}{55} & $2.8: 1$ \\
\hline \multicolumn{2}{|c|}{40} & \multicolumn{2}{|c|}{60} & $2.7: 1$ \\
\hline \multicolumn{2}{|c|}{35} & \multicolumn{2}{|c|}{65} & 2.6:1 \\
\hline & & 7 & & 2.6:1 \\
\hline & & 7 & & $2.5: 1$ \\
\hline & & 8 & & $2.4: 1$ \\
\hline & & 8 & & $2.4: 1$ \\
\hline & & 9 & & $2.3: 1$ \\
\hline & & 9 & & $2.3: 1$ \\
\hline & & 10 & & $2.2: 1$ \\
\hline
\end{tabular}

compared favourably with those obtained by Viera da mota et al. [17]. A lower value $(4.65 \pm 0.01)$ was obtained with Ofada rice, ostensibly because of the difference in source. Ebuehi and Oyewole [14] reported a similar observation. The insoluble (IDF) and soluble (SDF) dietary fibre fractions $(\mathrm{g} / 100 \mathrm{~g} \mathrm{DM})$ for plantain flour were $(10.32 \pm 0.02)$ and $(2.81 \pm 0.02)$ respectively, yielding an IDF:SDF ratio of 3.68:1. (Table 3 ). These figures contrast sharply with those for Ofada rice: Insoluble (3.20 \pm 0.01$)$ and soluble $(1.45 \pm 0.02)$ dietary fibre fraction amounting to an IDF:SDF ratio 2.22:1. Evidently, the soluble fibre fractions of Ofada rice $(31 \%)$ is higher than that of Plantain flour $(21 \%)$. These variations are significant in the functional characteristics and physiological effects of these products [8].

Blends of plantain and Ofada rice flours: Calculated IDF:SDF ratio of different proportion of plantain and Ofada Rice flour are as shown in Table 3. Apparently, blends that had up to 50\% Ofada Rice and above had an IDF:SDF ratio of 2.2:1 to 2.8:1. These ratios appears not too remote from the 2:1 target ratio. Some four blends in this bracket along with three others randomly selected sufficed for subsequent sensory evaluation.

\section{Sensory evaluation of dough from reconstituted flour samples}

Mean scores for sensory attributes (texture, colour, taste, mouldability, Aroma, Mouth feel and overall acceptability) of the reconstituted Ofada - Plantain dough is quite revealing (Table 4). In terms of texture, sample NXS was most preferred with a mean sensory score of 7.33 closely followed by EBG (7.10), KDV (6.13), CKQ (6.00), MPU (5.43), LYF (5.30) and JZH (4.83) in that order. Though varied in scores, samples NXS, EBG and KDV are virtually the same, not significantly different $(\mathrm{P} \leq 0.05)$.
The least colour appeal was exhibited by sample LYF (5.13) contrasting sharply with those of NXS (7.97) the most preferred, again in this attribute. Sensory scores for other samples ranged within these two. Most panellists gave the highest sensory score to sample NXS (7.87) with others following KDV, EBG, JZH, LYF, MPU and CKQ in that order. Samples NXS and KDV were though not significantly different $(P \leq 0.05)$. Sample KDV was perceived as the best in terms of mouldability with a sensory score of 7.33 which compared favourably with that of sample NXS. The least sensory score was given to sample JZH owing to its sticky nature.

Aroma sensory score for JZH, MPU, CKQ, LYF were lower than those of NXS (6.90) and KDV (6.60), an indication of less preference though not significantly different. The same trend holds true for mouthfeel across the samples. In overall acceptability, samples NXS was the most preferred (7.53) which was closely followed by KDV, EBG, CKQ, LYF, MPU and JZH in that order.

A cursory look at the sensory scores indicates that NXS, KDV and EBG were the most preferred in all the attributes. The two best blend of the flours in terms of sensory perception were NXS (Ofada:plantain, 85:15) and EBG (Ofada:plantain, 50:50). These along with samples JZH (Ofada:plantain, 0:100) and KDV (Ofada:plantain, 100:0) sufficed for proximate and functional properties determinations.

\section{Proximate composition of Ofada-plantain flour blends}

The proximate composition (Moisture, protein, fat, Ash, crude fibre and carbohydrate) are as follows.

Moisture content: Moisture content of samples compared favourably with each other (10.4-11.2\%) while also indicating a high percentage of dry matter (Table 5). Similar observations have been made with 100\% Ofada Rice [27] and 100\% plantain [28] flours. These values are safely below the generally accepted $14 \%$ moisture content after which good keeping quality may be at risk.

Protein content: Sample blends (NXS and KDV) with higher inclusion of Ofada Rice flour had lower protein content $(8.18 \pm 0.01 \%)$. This parameter has been recognised to exert a significant influence on functional properties [29].

Fat content: All samples generally had low fat $(<1.69 \%)$, an indication of reduced likelihood of rancidity. Abioye et al. [30] reported similar values $(0.75 \pm 0.01 \%)$ with $100 \%$ plantain flour.

Ash content: The ash content is a reflection of the level of minerals (1.17-1.60\%) in the samples.

Crude fibre: All the four samples were significantly different $(\mathrm{P}<$ $0.05)$ from one another; JZH having the highest value of 0.73 , followed by EBG $(0.60 \pm 0.01)$ NXS $(0.31 \pm 0.01)$ and $\operatorname{KDV}(0.27 \pm 0.01)$ in that order.

Carbohydrate: Samples EBG, KDV and NXS compared favourably with each other in their carbohydrate content but are at variance with sample JZH.

\section{Functional properties}

The results for the functional properties [comprising Water Absorption Capacity (WAC), Swelling Power (SP), Solubility Index (SI), Bulk Density (BD)] and $\mathrm{pH}$ for Plantain-Ofada flour mixes are shown in Table 6.

Water absorption capacity: Water absorption capacity of OfadaPlantain flours increased with rising Ofada flour substitution; plantain 
Arueya GL (2018) Development and characterization of dumpling dough with 'optimal' dietary fibre ratio using Ofada rice (Oryza Sativa L) and unripe plantain (Musa Paradisiaca AAB) fruit

Table 4. Sensory evaluation of dough from reconstituted Ofada-Plantain flour blends (Sample with the same alphabetical letter of superscript across rows are not significantly different $(\mathrm{P}<0.05)$. Samples JZH:100\% Plantain flour, LYF:85\% Plantain flour and 15\% Ofada flour, MPU:65\% Plantain flour and 35\% Ofada flour, EBG:50\% Plantain flour and 50\% Ofada flour, CKQ:30\% Plantain flour and 70\% Ofada flour, NXS: $15 \%$ Plantain flour and $85 \%$ Ofada flour, KDV: $100 \%$ Ofada flour)

\begin{tabular}{|c|c|c|c|c|c|c|c|}
\hline Quality attribute & JZH & LYF & MPU & EBG & CKQ & KDS \\
\hline Texture & $4.83 \pm 1.72^{\mathrm{c}}$ & $5.30 \pm 1.39^{\mathrm{bc}}$ & $5.43 \pm 1.41^{\mathrm{bc}}$ & $7.10 \pm 1.40^{\mathrm{a}}$ & $6.00 \pm 1.41^{\mathrm{b}}$ & $7.33 \pm 1.69^{\mathrm{a}}$ & $6.13 \pm 1.80^{\mathrm{a}}$ \\
\hline Colour & $5.67 \pm 1.42^{\mathrm{c}}$ & $5.13 \pm 1.85^{\mathrm{c}}$ & $5.37 \pm 1.87^{\mathrm{c}}$ & $6.77 \pm 1.38^{\mathrm{b}}$ & $6.70 \pm 1.32^{\mathrm{b}}$ & $7.97 \pm 1.13^{\mathrm{a}}$ & $7.57 \pm 1.36^{\mathrm{a}}$ \\
\hline Taste & $5.97 \pm 1.52^{\mathrm{bc}}$ & $5.97 \pm 1.25^{\mathrm{bc}}$ & $5.67 \pm 1.42^{\mathrm{c}}$ & $6.43 \pm 1.41^{\mathrm{b}}$ & $5.40 \pm 1.45^{\mathrm{c}}$ & $7.87 \pm 1.20^{\mathrm{a}}$ & $7.47 \pm 1.17^{\mathrm{a}}$ \\
\hline Mouldability & $4.77 \pm 1.74^{\mathrm{d}}$ & $5.30 \pm 1.58^{\mathrm{cd}}$ & $5.70 \pm 1.29^{\mathrm{bc}}$ & $6.53 \pm 1.33^{\mathrm{ab}}$ & $6.10 \pm 1.79^{\mathrm{bc}}$ & $7.23 \pm 1.61^{\mathrm{a}}$ & $7.33 \pm 1.56^{\mathrm{a}}$ \\
\hline Aroma & $5.47 \pm 1.70^{\mathrm{c}}$ & $5.93 \pm 1.95^{\mathrm{bc}}$ & $5.50 \pm 1.59^{\mathrm{c}}$ & $6.13 \pm 1.83^{\mathrm{abc}}$ & $5.60 \pm 1.33^{\mathrm{c}}$ & $6.90 \pm 1.18^{\mathrm{a}}$ & $6.60 \pm 1.13^{\mathrm{ab}}$ \\
\hline Mouth feel & $5.47 \pm 1.70^{\mathrm{b}}$ & $5.40 \pm 1.59^{\mathrm{b}}$ & $5.70 \pm 1.37^{\mathrm{b}}$ & $6.17 \pm 1.49^{\mathrm{ab}}$ & $5.90 \pm 1.18^{\mathrm{b}}$ & $6.83 \pm 1.37^{\mathrm{a}}$ & $6.90 \pm 1.60^{\mathrm{a}}$ \\
\hline Overall Acceptability & $5.40 \pm 1.65^{\mathrm{c}}$ & $5.97 \pm 1.25^{\mathrm{bc}}$ & $5.57 \pm 1.22^{\mathrm{c}}$ & $6.40 \pm 1.69^{\mathrm{b}}$ & $6.03 \pm 1.22^{\mathrm{bc}}$ & $7.53 \pm 1.28^{\mathrm{a}}$ & $7.30 \pm 1.47^{\mathrm{a}}$ \\
\hline
\end{tabular}

Table 5. Proximate composition of Ofada- Plantain flour blends (EBG: $50 \%$ Plantain flour and $50 \%$ Ofada flour, JZH: $100 \%$ Plantain flour, KDV: $100 \%$ Ofada flour, NXS: $15 \%$. Plantain flour and $85 \%$ Ofada flour. Values are means of triplicates tests. Values with different superscripts within column are significantly different $(\mathrm{P}<0.05)$ )

\begin{tabular}{|c|c|c|c|c|c|c|c|}
\hline & Moisture (\%) & Protein (\%) & Fat (\%) & Ash (\%) & Fibre (\%) & CHO (\%) & Energy (Kcal/100 g) \\
\hline EBG & $10.87 \pm 0.26^{\mathrm{b}}$ & $8.32 \pm 0.01^{\mathrm{b}}$ & $0.55 \pm 0.01^{\mathrm{d}}$ & $1.54 \pm 0.00^{\mathrm{b}}$ & $0.60 \pm 0.01^{\mathrm{b}}$ & $78.11 \pm 0.27^{\mathrm{a}}$ & $350.67 \pm 0.98^{\mathrm{b}}$ \\
\hline JZH & $11.20 \pm 0.01^{\mathrm{a}}$ & $8.70 \pm 0.01^{\mathrm{a}}$ & $0.84 \pm 0.03^{\mathrm{b}}$ & $1.59 \pm 0.01^{\mathrm{a}}$ & $0.73 \pm 0.00^{\mathrm{a}}$ & $76.94 \pm 0.04^{\mathrm{b}}$ \\
\hline KDV & $10.40 \pm 0.01^{\mathrm{c}}$ & $8.18 \pm 0.01^{\mathrm{c}}$ & $1.69 \pm 0.01^{\mathrm{a}}$ & $1.34 \pm 0.01^{\mathrm{c}}$ & $0.27 \pm 0.01^{\mathrm{d}}$ & $78.12 \pm 0.02^{\mathrm{a}}$ & $350.12 \pm 0.05^{\mathrm{b}}$ \\
\hline NXS & $11.20 \pm 0.00^{\mathrm{a}}$ & $8.18 \pm 0.01^{\mathrm{c}}$ & $0.78 \pm 0.01^{\mathrm{c}}$ & $1.18 \pm 0.01^{\mathrm{d}}$ & $0.31 \pm 0.01^{\mathrm{c}}$ & $78.35 \pm 0.01^{\mathrm{a}}$ & $360.41 \pm 0.03^{\mathrm{a}}$ \\
\hline
\end{tabular}

Table 6. Functional properties of Ofada-Plantain flour blends (EBG: 50\% Plantain flour and 50\% Ofada flour, JZH: 100\% Plantain flour, KDV: $100 \%$ Ofada flour, NXS: $15 \%$ Plantain flour and $85 \%$ Ofada flour.WAC, water absorption capacity; SP, swelling power; SOL, solubility; BD, Bulk density values are means of triplicates tests. Values with different superscripts within a column are significantly different $(\mathrm{P} \leq 0.05))$

\begin{tabular}{|c|c|c|c|c|}
\hline SAMPLE & WAC (\%) & SP(\%) & SOL (\%) & BD $\left(\mathbf{g} / \mathbf{c m}^{3}\right)$ \\
\hline EBG & $169.93 \pm 0.04^{\mathrm{c}}$ & $73.89 \pm 0.00^{\mathrm{b}}$ & $12.45 \pm 0.01^{\mathrm{c}}$ & $0.70 \pm 0.01^{\mathrm{c}}$ \\
\hline JZH & $123.51 \pm 0.07^{\mathrm{c}}$ & $143.18 \pm 0.01^{\mathrm{a}}$ & $6.93 \pm 0.01^{\mathrm{d}}$ & \\
\hline KDV & $290.15 \pm 0.03^{\mathrm{a}}$ & $32.20 \pm 0.01^{\mathrm{d}}$ & $12.94 \pm 0.01^{\mathrm{b}}$ & $0.71 \pm 0.00^{\mathrm{c}}$ \\
\hline NXS & $222.67 \pm 0.02^{\mathrm{b}}$ & $39.98 \pm 0.01^{\mathrm{c}}$ & $13.41 \pm 0.01^{\mathrm{a}}$ & $0.87 \pm 0.01^{\mathrm{a}}$ \\
\hline
\end{tabular}

flour $(100 \%)$ having the least WAC $(123.51 \pm 0.07)$ and Ofada flour the highest (290.15 \pm 0.03$)$. Addition of Ofada flour to Plantain flour appears to impart high water binding property, thus enhancing the reconstitution ability and textural properties obtainable from the blend [31]. The WAC of $100 \%$ Plantain flour compared favourably with

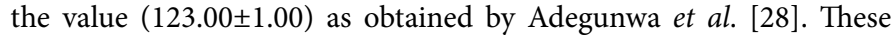
differences in absorption capacity may be traceable to variations in concentration of hydrophilic constituents such as amylose as well as the stability of their intrinsic starch crystalline structure [32].

Swelling power and solubility index: There was significant difference $(\mathrm{P} \leq 0.05)$ in the swelling power of the samples [100\% Plantain flour $(143.18 \pm 0.01) ; 100 \%$ Ofada flour $(32.20 \pm 0.01)$. This property is a function of flour particle size, varietal source and processing [32]. Soluble dietary fibre fractions of these flours may also be a factor here as they reportedly bind and retain several times their weight of water if up to about $15 \%$ [8].

The solubility index of the samples ranged from $6.93 \pm 0.01$ to $13.41 \pm 0.01$, also reflecting wide margin of differences.

Bulk density: The values obtained for Bulk density $(0.70 \pm 0.01)$ to $\left(0.87 \pm 0.01 \mathrm{~g} / \mathrm{cm}^{3}\right)$ compared favourably with those observed by Adegunwa et al. [28] for 100\% Plantain flour. The bulk density is a key determinant in the choice of packaging in the food industry [31].

pH: The $\mathrm{pH}$ of the samples varied between $5.31 \pm 0.01$ and $5.73 \pm 0.02$, all about the value (5.50) reported by Abioye et al. [30] for $100 \%$ Plantain flour.

\section{Pasting properties}

The pasting properties (including pasting temperature, peak time and peak viscosity) of Ofada-Plantain flour are as indicated on Table 7.

Pasting temperature: The pasting temperature (the least temperature required to cook) Ofada-plantain samples ranged between
$49.55 \pm 1.30^{\circ} \mathrm{C}$ and $84.28 \pm 0.89^{\circ} \mathrm{C}$. The $100 \%$ Ofada flour sample had the lowest pasting temperature of $49.55 \pm 1.30^{\circ} \mathrm{C}$. However, with as little as $15 \%$ substitution with Plantain flour, the pasting temperature jumped to $84.28 \pm 0.89$. Evidently pasting temperature appeared to increase with rising inclusion level of plantain flour in the blend to about $15 \%$ and there after began to drop. These can have profound implications for the stability of heat labile components in the blend as well as the cost of energy [33].

Peak time: The $100 \%$ Plantain flour had the lowest peak time $4.62 \pm 0.04 \mathrm{~min}$ while the samples $100 \%$ Ofada flour or $85 \%$ Ofada substitution took about one and half times that duration to cook. The higher starch component in these latter samples may account for this phenomenon [34]. The peak time is a measure of the cooking time [35].

Peak viscosity: Aside from the $(602.97 \pm 9.43$ RVU) sample viscosity for $100 \%$ Plantain flour, the next peak was $209.39 \pm 0.96$ RVU (Ofada:plantain) (Table 7) and compared favourably with the 215.33 RVU reported for Wheat flour [36]. Peak viscosity provides an indication of the viscous load likely to be encountered during mixing [37].

Trough: Trough viscosity is the minimum viscosity value in the constant temperature phase of the RVA profile and measures the ability of paste to withstand breakdown during cooling [26]. The values obtained ranged between 295.59 RVU (100\% plantain flour) and 15.31 RVU (100\% Ofada flour) (Table 7$)$. These values are significant as it indicates stability of the starch gel during cooking. The lower the value the more stable is the starch gel.

Breakdown: The breakdown is a reflection of the ability of a flour to resist heating and shear stress during cooking [34]. Breakdown mean values of the flour samples were between 3.39 and $305.70 \mathrm{RVU}$.

Final viscosity: The final viscosity was highest in $100 \%$ plantain flour $(428.19 \pm 0.10 \mathrm{RVU})$ but least in $100 \%$ Ofada flour $(34.44 \pm 0.10$ 
RVU). These variations may be attributable to inherent amylose content of the blends and their tendency towards molecular aggregation [38].

Set back: The viscosity after cooling to $50^{\circ} \mathrm{C}$ represents the setback or viscosity of cooked paste and ranged between $22.47 \pm 0.34 \mathrm{RVU}$ (100\% Ofada flour) and $130.94 \pm 1.3$ (50\% Ofada flour and 50\% plantain flour). This appears to increase with rising inclusion level of plantain flour up to $50 \%$. Sample NXS with a setback value of $68.92 \pm 0.43 \mathrm{RVU}$ is close to the setback value obtained for wheat flour (71.25) RVU [35]. The setback viscosity exhibits the tendency of the dough to undergo retrogradation, a phenomenon associated with the dough becoming firmer and increasingly resistant to enzymatic attack [4]. Instructively this has a serious implication for the digestibility of the dough when consumed [39].

\section{Nutritional evaluation}

\section{Food and water intake of albino rats}

There were no significant differences in food and water intake between normal and hypercholesterolemic rats for all groups at the end of induction (Table 8). The experimental Ofada- Plantain diets also did not significantly affect the food and water consumption in the respective groups. The ranges of food consumptions of basal (control) and hypercholesterolemic groups were between (80-81) and (82-84) $\mathrm{g} / \mathrm{kg} /$ day, respectively. Similarly the ranges of water consumptions of basal (control) and hypercholesterolemic groups were between (148$163)$ and (150-158) $\mathrm{ml} / \mathrm{kg} /$ day, respectively.

\section{Feed treatment on mean weight of albino rats}

The body weight gain of the rats during the experimental period is as depicted in Table 9. There were significant differences in the pattern of weight gained between the animals fed HCD diet and those fed basal diet. Hypercholesterolemic diet increased the body weight of rats with between $49-78 \%$ at the end of induction period. This was significantly higher than the value (38\%) obtained in animals fed basal (control) diet (CON). At the end of second feeding period (from the end of induction), the gain in body weight dropped [6.3\% (Ofada-Plantain 85:15); 8.4\% (Ofada-Plantain 50:50)]. This contrasts sharply with the gain in weight for high cholesterol (HCD) (41\%) and basal (CON) (45.2\%) diets fed rats.

Evidently, the animals fed on the control diet maintained a consistent large weight gain throughout the period just like high cholesterol diet (HCD). However the rats fed on treatment diets [(Ofada plantain, (85:15); Ofada:plantain, (50:50))] gained little weight in the third and fourth week in comparison to control (CON) and HCD groups Although weight gain occurred across all groups, there was marked difference in the rate of occurrence. The fastest gain in weight observed was in the HCD, CON, Ofada:plantain (50:50) and Ofada plantain (85:15) in that order. Harnafi et al. [40] reported similar pattern in hyper cholesterolemic rats fed diets enriched with sweet Basil (Ocimum basilicum L). Foods with low weight gain potentials have proved quite valuable in the management of obesity [41].

\section{Biochemical parameters}

At the end of the treatment period following induction, an increase in concentrations - 8.0, 8.8, 6.3 and $10.3 \%$ were observed for Serum total cholesterol (TC), total glycerides (TG), high density lipoprotein (HDL) (Good cholesterol) and low-density lipoprotein (LDL) (Bad cholesterol) respectively among Rats fed control diet (CON) (Table 10). These values (except for HDL) further rose significantly in rats fed high cholesterol diet (HCD) and understandably so (nature of diet) especially in low density lipoprotein (73.5\%). An increase in LDL has been recognized as one of the risk factors for the development of atherosclerosis [42] The incorporation of Ofada-plantain flour blend however exerted some reduction in TC (0.9-2.6\%) and LDL (48.7-53.9\%) (Table 10). The hypocholesterolemic properties of these diets particularly it's decreased LDL tendencies may be related to the activities of the soluble fraction of the dietary fibres [43]. Although

Table 7. Pasting characteristics of Ofada-Plantain flour blends (EBG: 50\% Plantain flour and 50\% Ofada flour, JZH: 100\% Plantain flour, KDV: $100 \%$ Ofada flour, NXS: $15 \%$ Plantain flour and $85 \%$ Ofada flour. Peak viscosity is maximum viscosity developed during or after the heating portion of the test; Trough is minimum viscosity after the peak normally occurring after the commencement of the sample cooling; Breakdown is peak viscosity minus trough viscosity. Final viscosity is viscosity at the end of the test; set back is final viscosity minus peak viscosity. Peak time ( $\mathrm{min})$ is the time taken to attain the peak viscosity)

\begin{tabular}{|c|c|c|c|c|c|c|c|}
\hline SAMPLE & Peak Viscosity & Trough & Breakdown (RVU) & Final Viscosity & Set Back & Peak Time & $\begin{array}{c}\text { Pasting Temperature } \\
\left({ }^{\circ} \mathrm{c}\right)\end{array}$ \\
\hline EBG & $209.39 \pm 0.96^{\mathrm{b}}$ & $194.92 \pm 0.87^{\mathrm{b}}$ & $14.47 \pm 0.09^{\mathrm{b}}$ & $325.86 \pm 2.79^{b}$ & $130.94 \pm 1.93^{\mathrm{a}}$ & $5.00 \pm 0.00^{\mathrm{b}}$ & $82.45 \pm 0.00^{\mathrm{b}}$ \\
\hline JZH & $602.97 \pm 9.43^{\mathrm{a}}$ & $297.28 \pm 1.69^{\mathrm{a}}$ & $305.70 \pm 7.75^{\mathrm{a}}$ & $428.19 \pm 0.10^{\mathrm{a}}$ & $130.92 \pm 1.59^{\mathrm{a}}$ & $4.62 \pm 0.04^{c}$ & $81.03 \pm 0.03^{\mathrm{b}}$ \\
\hline KDV & $19.36 \pm 0.19^{\mathrm{d}}$ & $15.97 \pm 0.24^{\mathrm{d}}$ & $3.39 \pm 0.05^{\mathrm{c}}$ & $38.44 \pm 0.10^{\mathrm{d}}$ & $22.47 \pm 0.34^{\mathrm{c}}$ & $7.00 \pm 0.00^{\mathrm{a}}$ & $49.55 \pm 1.30^{c}$ \\
\hline NXS & $54.33 \pm 0.33^{\mathrm{c}}$ & $48 . .41 \pm 0.58^{c}$ & $5.92 \pm 0.14^{\mathrm{c}}$ & $117.33 \pm 1.01^{\mathrm{c}}$ & $68.92 \pm 0.43^{b}$ & $7.00 \pm 0.00^{\mathrm{a}}$ & $84.28 \pm 0.89^{\mathrm{a}}$ \\
\hline
\end{tabular}

Table 8. Comparison of food and water consumption of albino rats fed with different diets (CON- Basal diet, HCD- High cholesterol diet, Ofada-Plantain (50:50) -HC + Ofada rice flour $50 \%$ and Plantain flour 50\%, Ofada-Plantain (85:15)- HC + Ofada rice flour $85 \%$ and Plantain flour $15 \%)$

\begin{tabular}{|c|c|c|c|}
\hline & \multicolumn{2}{|c|}{ Food Consumption (g/kg rat/day) } & \multicolumn{2}{c|}{ Water Consumption (ml/kg rat/day) } \\
\hline Group & End of induction & End of treatment & End of induction \\
\hline ON & $80 \pm 2$ & $81 \pm 1$ & $148 \pm 3$ \\
\hline HCD & $82 \pm 3$ & $83 \pm 2$ & $150 \pm 2$ \\
\hline Ofada-Plantain (85:15) & $83 \pm 2$ & $84 \pm 1$ & $154 \pm 1$ \\
\hline
\end{tabular}

Table 9. Comparison of Body weight of rats fed different diets at the end of induction, and after treatment (CON is Basal diet, HCD is high cholesterol diet, Ofada-Plantain (50:50) -HC + Ofada rice flour $50 \%$ and Plantain flour 50\%, Ofada-Plantain (85:15)- HC + Ofada rice flour $85 \%$ and Plantain flour $15 \%)$

\begin{tabular}{|c|c|c|c|}
\hline Group & Initial body weight & End of Induction \\
\hline CON & $96.20 \pm 7.16^{\mathrm{a}}$ & $132.60 \pm 8.08^{\mathrm{b}}$ \\
\hline HCD & $104.60 \pm 7.50^{\mathrm{a}}$ & $159.20 \pm 8.93^{\mathrm{a}}$ \\
\hline Ofada-Plantain (85:15) & $85.00 \pm 43.40^{\mathrm{a}}$ & $151.60 \pm 11.22^{\mathrm{ab}}$ \\
\hline Ofada-Plantain (50:50) & $101.20 \pm 13.66^{\mathrm{a}}$ & $192.60 \pm 11.74^{\mathrm{ab}}$ \\
\hline
\end{tabular}


Arueya GL (2018) Development and characterization of dumpling dough with 'optimal' dietary fibre ratio using Ofada rice (Oryza Sativa L) and unripe plantain (Musa Paradisiaca AAB) fruit

Table 10. Effect of different diets on lipid profiles in rats (CON- Basal diet, HCD- High cholesterol diet, Ofada-Plantain (50:50) -HC + Ofada rice flour 50\% and plantain flour 50\%, OfadaPlantain (85:15)- HC Ofada rice flour 85\% and Plantain flour 15\%

\begin{tabular}{|c|c|c|c|c|c|c|c|c|}
\hline & \multicolumn{2}{|c|}{ TC(mg/d) } & \multicolumn{2}{|c|}{ TG(mg/d) } & \multicolumn{2}{|c|}{ HDL(mg/dl) } \\
\hline Group & Initial & Final & Initial & Final & \multicolumn{2}{|c|}{ Initial } & Final & Initial \\
\hline CON & $62.60 \pm 10.14$ & $67.60 \pm 9.81$ & $52.20 \pm 12.21$ & $56.80 \pm 12.15$ & $32.00 \pm 7.68$ & $34.00 \pm 7.35$ & $20.16 \pm 5.53$ & $22.24 \pm 5.37$ \\
\hline HCD & $75.60 \pm 9.40$ & $85.60 \pm 9.94$ & $63.20 \pm 12.52$ & $73.20 \pm 12.11$ & $39.00 \pm 6.44$ & $29.4 \pm 6.80$ & $23.96 \pm 6.68$ & $41.56 \pm 7.29$ \\
\hline OfaPla (15:85) & $64.00 \pm 8.75$ & $63.40 \pm 8.08$ & $57.40 \pm 11.70$ & $66.20 \pm 11.78$ & $34.40 \pm 6.43$ & $41.80 \pm 6.8$ & $18.12 \pm 8.35$ & $8.36 \pm 5.13$ \\
\hline OfaPla (50:50) & $62.20 \pm 10.94$ & $60.60 \pm 8.14$ & $49.40 \pm 11.97$ & $55.20 \pm 12.44$ & $36.40 \pm 3.85$ & $43.40 \pm 3.78$ & $15.92 \pm 7.65$ & $8.16 \pm 7.87$ \\
\hline
\end{tabular}

not significantly different, Ofada:plantain flour blend (85:15, IDF/SDF 2.4:1) appears generally better than the (50:50, IDF/SDF 2.8:1) variant in this aforementioned characteristic. It is also noteworthy that these variants boosted HDL concentrations 21.5\% (Ofada:plantain, 85:15) and 19.2\% (Ofada:Plantain, 50:50) in the test period. Interestingly also, there was no recorded death among the Rats across all groupings. This reinforces to some extent the safety of the diets.

\section{Conclusion}

Acceptable dumpling doughs with near optimum dietary fibre ratio using Ofada rice and unripe plantain fruit has been developed. Its low weight gain and hypocholesterolemic potentials was evident. A wide consumption of this food dumpling may make a difference in mitigating rising cases of overweight and obesity in sub-Saharan Africa

\section{Conflict of interest}

The authors have declared no conflict of interest.

\section{References}

1. Awoyale W, Maziya-Dixon B, Sanni LO, Shittu TA (2015) Effect of water yam (Dioscoreaalata) flour fortified with distiller's spent grain on nutritional, chemical, and functional properties. Food Sci Nutr 4: 24-33. [Crossref]

2. Bolade MK (2009) Effect of flour production methods on the yield, physical chemical properties of maize flour and rheological characteristics of a maize based nonfermented food dumpling. African Journal of Food Science 3: 288-298.

3. Hahn SK (2017) An Overview of traditional processing and utilization of Cassava in Africa. Available on http://www.fao/wairdoc. Accessed on the 02/07/2017.

4. Ihekoronye AI, Ngoddy PO (1985) Integrated food science and technology for the tropics. 1st ed. McMillan publishers, pp: 245, 270-281.

5. Jisha S, Padmaja G (2011) Whey protein concentrate fortified baked goods from cassava-based composite flours: Nutritional and functional properties. Food and Bioprocess Technology 4: 92-101

6. Awoyale W, Maziya Dixon B, Sanni LO, Shittu TO (2011) Nutritional and Sensory properties of a maize based snack food (kokoro) supplemented with treated distillers spent Grain. International Journal of Food Science and Technology 46: 1609-1620.

7. Roberta MSA Mariana SLF, Edira BAG (2014) Functional capacity of flour obtained from residue of fruit and vegetables. International Food Research Journal 21: 16751681.

8. Figuerola F, Hurtado ML Estevez AN, Chifelle I (2005) Fibre Concentrates from apple pomace and citrus peel as potential fibre sources for food enrichment. Food Chem 91: 395-401.

9. Devi PB, Vijayabharathi R, Sathyabama S, Malleshi NG, Priyadarisini B (2014) Health benefits of finger millet (Eleusine Coracana L) Polyphenols and dietary fibre: a review. Journal of Food Science and Technology 51: 1021-1040.

10. Sedibe MH, Pisa PT, Feeley AB, Pedro TM, Kahn K, et al. (2018) Dietary Habits and Eating practices and their Association with Overweight and Obesity in Rural and Urban Black South Africa Adolescents. Nutrients 10: 145.

11. Song Y, Park MJ, Park HY and Joung H (2010) Secular trends in dietary patterns and obesity related factors in Korean adolescents aged 10-19 year. International Journal of Obesity 34: 48-56.

12. Anderson JW, Baird P, Davis RH Jr, Ferreri S, Knudtson M, et al. (2009) Health benefits of dietary fiber. Nutr Rev 67: 188-205. [Crossref]
13. Howarth NC, Saltzman E, Roberts SB (2001) Dietary fiber and weight regulation. Nutr Rev 59: 129-139. [Crossref]

14. Ebuehi OAT, Oyewole AC (2007) Effect of Cooking and Soaking on Physica Characteristics, Nutrient Com-position and Sensory Evaluation of Indigenous and Foreign Rice Varieties in Nigeria. African Journal of Bio-tech 6: 1016-1020.

15. Otegbayo BO, Samuel FO, Fashakin JB (2001) Effect of Parboiling on PhysicoChemical Qualities of Two Local Rice Varieties in Nigeria. Journal of Food Technology Africa 6: 130-132.

16. Food and Agriculture Organisation (FAO) (1999) Plantain Post-harvest Operation INPho - Postharvest Compedium.

17. Vieira da Mota R, Lajolo FM, Cordenunsi BR, Ciacco C (2000) Composition and Functional Proper ties of Banana Flour from Different Varieties. Starch/Stärke 52: 6368.

18. Adom T, Puonne T, Villiers A, Kengre AP (2017) Prevalence of Obesity and Overweight in African learners: a protocol for systematic review and Meta-analysis. British Medical Journal 7: e013538

19. Ogazi PO (1984) Plantain production, processing and utilization. Paman Associate Publication, Oxford, London, UK, Edinburg, Melbourne, Australia, pp: 565.

20. AOAC (2000) Official Methods of Analysis. 17th ed. Association of Official Analytical Chemists International. Washington, DC, USA.

21. AOAC (1990) Official Methods of Analysis of the Association of Official Analytical Chemists, 15th ed, AOAC, Arlington, Virginia, USA.

22. Obiegbuna JZ, Baba SS (2001) Proximate composition and secondary properties of peanut and melon seed butter blends. Journal of Sustainable Agriculture and The Environment 3: 326-330.

23. Akpapunam MA, Markakis P (1981) Physico-Chemical and Nutritional aspects of Cowpea Flour. Journal of Food Science 46: 972-973.

24. Takashi S, Seeb PA (1988) Paste and gel properties of prime corn and wheat starches with and without native lipids. Cereal Chemistry 65: 474-483

25. Elkhalifa AO, Schiffler B, Bernhardt R (2005) Effect of fermentation on the functional properties of sorghum flour. Food Chemistry 92: 1-5.

26. New port Scientific (1998). Application manual for the Rapid View Analyze using Thermocline for Windows. Newport Scientific Pty Ltd, Warriewood, pp: 2-26.

27. Adebayo-Oyetoro AO, Olatidoye OP, Ogundipe FO, Ogundipe OO, Balogun OI, et al. (2011) Evaluation of Proximate Composition and Functional Properties of Ofada Rice (Oryza Sativa) Flour Blended with Bambara Groundnut (Vigna subterranean L). Journal of Agriculture and Veterinary Sciences 3: 60-66.

28. Adegunwa MOI, Adebowale AA, Bakare HAL, Ovie SG (2014) Compositional Characteristics and Functional Properties of Instant Plantain-Breadfruit Flour. International Journal of Food Research 1: 1-7.

29. Fitzgerald MA, Martin M, Ward RM, Park WD, Shead HJ (2003) Viscosity of rice flour: a rheological and biological study. J Agric Food Chem 51: 2295-2299. [Crossref]

30. Abioye VF, Ade-Omowaye BIO, Babarinde GO, Adesigbin MK (2011) Chemical, physico-chemical and sensory properties of soy-plantain flour. African Journal of Food Science 5: $176-180$.

31. Adebowale AA, Sanni SA, Oladapo FO (2008) Chemical, functional and sensory properties of instant yam breadfruit flour. Niger. Food Journal 26: 2-12.

32. Chandra S, Singh S, Kumari D (2015) Evaluation of functional properties of composite flours and sensorial attributes of composite flour biscuits. J Food Sci Technol 52: 36813688. [Crossref]

33. Ikegwu OJ, Okechukwu PE, Ekumankana EO (2010) Physico-Chemical and Pasting Characteristics of Flour and Starch from Achi Brachystegia eurycoma Seed. Journal of Food Technology 8: 58-68 
Arueya GL (2018) Development and characterization of dumpling dough with 'optimal' dietary fibre ratio using Ofada rice (Oryza Sativa L) and unripe plantain (Musa Paradisiaca AAB) fruit

34. Ajatta MA, Akinola SA, Osundahunsi OF (2016) Proximate, functional and pasting properties of composite flour made from wheat, breadfruit and cassava starch. Applied Tropical Agriculture 21: 158-165.

35. Adebowale YA, Adeyemi IA, Oshodi AA(2005) Functional and physicochemical properties of flour of six Mucuna Species. African Journal of Biotechnology 4: 1461-1468.

36. Arisa NU, Adelekan AO, Alamu AE, Ogunfowora EJ (2013) The Effect of Pretreatment of Plantain (Musa Parasidiaca) Flour on The Pasting and Sensory Characteristics of Biscuit. International Journal of Food and Nutrition Science 2: 10-24

37. Maziya-Dixon BA, Dixon GO, Adebowale AA (2004) Targeting different end uses of cassava: genotypic variations for cyanogenic potentials and pasting properties. A paper presented at ISTRC-AB Symposium, 31 October - 5 November 2004, Whitesands Hotel, Mombassa, Kenya.

38. Miles MJ, Morris VJ, Ring SG (1985) Gelation of amylose. Carbohydrate Research 135: $257-269$.
39. Shittu TA, Lasekan OO, Sanni LO, Oladosu MO (2001) The effect of drying methods on the functional and sensory characteristics of pukuru-a fermented cassava product ASSET-An International Journal 1: 9-16.

40. Harnafi H, Aziz M, Armrani S (2009) Sweet Basil (Ocimum basilicum L.) improves lipid metabolism in hypercholesterolemic rats. E-SPEN, the European e-J. Clinical Nutrition and Metabolism 4: 181-186.

41. Sunkara R, Verghese M (2014) Functional Foods for Obesity Management. Food and Nutrition Science 5: 1359-1369.

42. Getz GS, Reardon CA (2006) Diet and Murine atherosclerosis. Arteriosclerosis, Thrombosis Vascular Biol 26: 242-249.

43. Chawla R, Patil GR (2010) Soluble Dietary Fibre. Compr Rev Food Sci Food Saf 9 178-195.

Copyright: @2018 Arueya GL. This is an open-access article distributed under the terms of the Creative Commons Attribution License, which permits unrestricted use, distribution, and reproduction in any medium, provided the original author and source are credited. 